\title{
ENSURING EXCHANGE RATE STABILITY: IS RETURN TO GOLD (DINAR) POSSIBLE?
}

\author{
Zubair Hasan ${ }^{1}$ \\ Professor, Department of Economics \\ Faculty of Economics and Management Sciences \\ International Islamic University of Malaysia, Selangor Dar-ul-Ehsan \\ E-mail: zubair@iiu.edu.my or zubhas@hotmail.com
}

\begin{abstract}
This paper shows that the recent euphoria in Malaysia to introduce Gold Dinar as money in Muslim countries is devoid of reason. Despite the destabilizing potential of the current monetary arrangements in the world, the return to gold is neither desired nor practicable. The Denarists, as some prefer to characterize the proponents, are palpably asking for the moon. It is argued here that the introduction of gold money in Muslim countries is in no way an Islamic imperative. And, if enforced, the system is likely to end in a chaotic failure. Sagacity, not emotion, must guide public policy.
\end{abstract}

\section{Introduction}

After the breakdown of Gold Standard in 1931, the world witnessed an era of freely fluctuating exchange rates between national currencies. The volatility did not prove conducive to the smooth flow of goods and capital across national borders. Balance of payments difficulties mounted for a number of countries, especially the developing ones. International trade and commerce was much hampered. Restoring stability to the lurching exchange rates the monetary disorder had caused was the call of the hour. But reforms had to wait until the end of the Second World War in 1945.

The International Monetary Fund (IMF) was established in 1946 to make arrangements for fixing exchange rates among national currencies with some measure of flexibility and help them tied over their balance of payments difficulties. The return to gold standard was not considered desirable, for a variety of reasons. The fixity part of exchange rates regimen was ensured through the agreed parities of various countries money to gold in the IMF scheme. But members could vary the gold parity of their currencies within $10 \%$ on either side of the current ratio without prior permission of the IMF. Thus, it was a system of 'managed flexibility'. The system worked fairly well as the

\footnotetext{
${ }^{1}$ The author is grateful to his Research Assistant Ms Nurhafiza Abdul Kader Malim for the valuable help she rendered in the preparation of this manuscript in terms of material collection, proof reading, and error correction. Thanks are also due to two anonymous referees for their valuable comments for improvement.
} 
US guaranteed to buy and sell gold at $\$ 35$ an ounce. But the country faced serious inflationary pressures and balance of payment problems aggravated further by a sharp jump in oil prices in the early 1970s. Eventually, the country had to pull off the dollar peg of the yellow metal. The gold prices rose sharply and have since continued to fluctuate abruptly as comparison of sections A and B in Figure 1 shows.

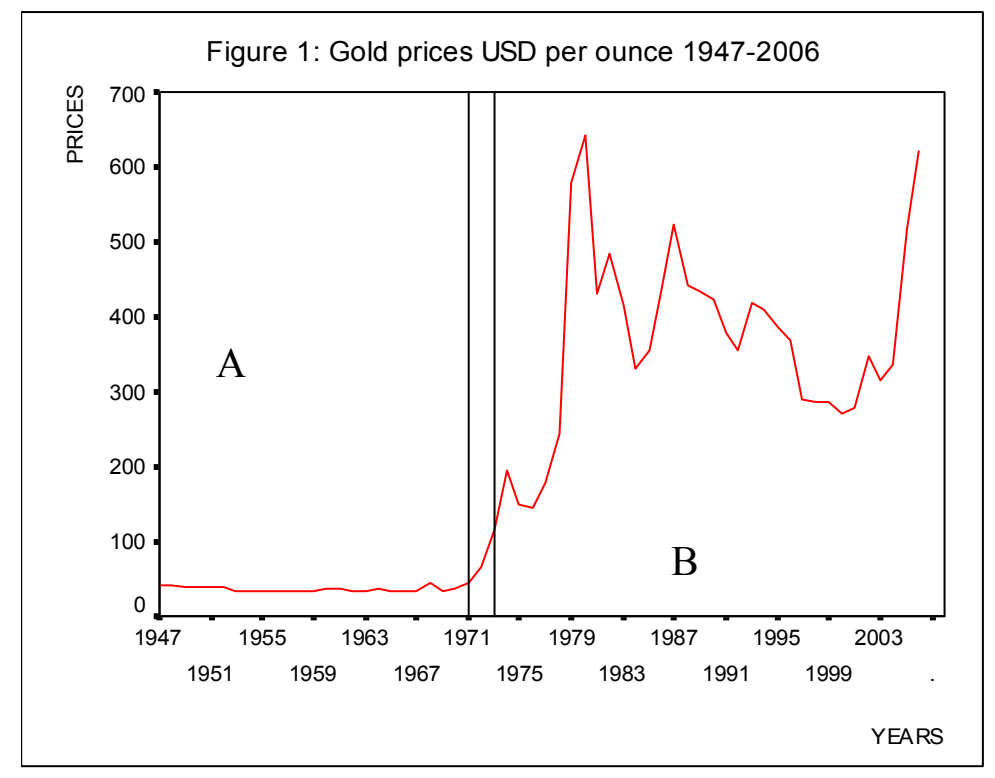

Source of data: web: US Gold

Once the gold-currency link was snapped, an era of freely fluctuating exchange rates again ensued. The IMF system was perforce reformed and the amended articles became operational in 1978. The new accord allows members to define the value of their currency in terms of criteria other than gold. Many countries now peg their money either to (i) some external currency or (ii) to the SDRs of the IMF or (iii) to a basket of other currencies $^{2}$. However the recent financial crises in various regions of the world -- their frequency, intensity and the conditions of IMF assistance to overcome them have caused much discomfiture to the developing countries. They are desperate - or so some believe - in search of a monetary system that could bring order to volatile exchange rates without making them compromise their freedom of action in national interests. After the 1997-98 financial crisis Malaysia was in particular searching for what could ensure economic

\footnotetext{
${ }^{2}$ For example, Malaysia kept its currency pegged to US dollar since 1998 until recently when it switched over to a trade-weighted basket of currencies this year. The Saudi riyal is linked to the IMF's SDRs.
} 
stability in the international transactions for the economy in years ahead. Not a few economists understandably saw the way out in the suggestion their then Prime Minister Tun Mahathir Mohamad made in early $2002^{3}$. He thought that Muslim countries must introduce Gold Dinar into the picture initially as a unit of account for settling foreign payments among themselves ${ }^{4}$. As experience is gained, its use could be widened as the pivot of a full fledged international currency acceptable to all. Articles and books were written in support of the idea. International conferences, seminars, and workshops were organized, as indicated in references, to explain and elaborate the modus operandi and benefits the scheme would confer. Many welcomed the measure in elation without pondering for a moment on the practical aspect of the concept, its policy implications, or its capabilities in the event of a crisis.

This paper argues that the introduction of Gold Dinar in any form -- much more as full blown money -- is not a workable idea. It defaults on the logical front, and may only add to the economic problems of Muslim countries, if perforce introduced. The argument is spread over five Sections including the Introduction. In Section 2 we briefly review the discussion on the gold dinar idea in the literature. Section 3 presents a bird's eye view of the performance of the gold-linked money until its last traces vanished in early 1970s. We shall show that gold standard does not achieve internal or external stability. If at all, the internal stability is sacrificed for external considerations. Section 4 argues why Gold cannot and should not be used even for payments settlement among Muslim countries. Section 5 winds up the argument with a few concluding remarks

\section{Literature Review}

The following review of literature aims at tracing briefly the treatment of the Gold Dinar notion in Islamic economics after the initial suggestion. It will also examine the efficacy of the arguments put forth in support of the notion.

\footnotetext{
${ }^{3}$ He unfolded the scheme on March 28 in his inaugural address to a conference on Islamic Capital Markets sponsored by the Malaysian Securities Commission

4. See Business Section of Star, $2^{\text {nd }}$ May, 2002 for the details and scope of the Malaysian proposal to use Gold Dinar initially as a currency in bilateral trading arrangements the country had with certain countries. It was expected to be adopted later by others on a multilateral or global scale as the presumption was that the arrangement would eliminate or mostly reduce the temptation to speculate and there will, thus, hardly be the need to hedge for covering any risk.
} 
The ball was formally set rolling by Meera, the leading advocate of the idea when he published his book The Islamic Gold Dinar in 2002. He presented a paper The Islamic Gold Dinar; Socioeconomic Perspectives, written with Aziz at an International Conference on Stable and Just Global Monetary System held at Kuala Lumpur the same year. This was essentially a preliminary work where the authors attempted to look "into the prospects and the challenges of introducing the Islamic gold dinar as a complementary currency within and among Muslim nations" in the light of what Malaysia had experienced during the 1997-98 financial crisis (2002, p.151) ${ }^{5}$. Meera followed these early explorations with more elaborate analyses in 2003, and 2004. One may take his last work as the final version of his views on the subject. Here, he blames almost all economic ills of modern capitalism on two factors (i) the institution of interest and (ii) the fiat money system churning out credit unabated (Prologue). In union, the two instruments have enabled, in his opinion, the rich Western nations -- US in particular- to plunder the developing countries of their wealth unceasingly (pp. 59-61). The argument seems more rhetoric than substantive. In any case, the author has not been able to drive it home either as a matter of logic or facts. It lacks documentation and is at places digressive $^{6}$.

Elaboration of these comments is not of much relevance to our argument. Important in Meera is his claim that a return to gold could alone restore order in an otherwise chaotic exchange arrangement reining the world at present. As a first step in that direction, Muslim countries who are, he thought, the worst victims of the Western exploitation must introduce gold dinar as a unit of account in their payments system ${ }^{7}$. They are advised to take their guidance from the facts: that (i) Islam prohibits interest in all its forms, and (ii) that gold dinar was the currency in the Muslim world until its

\footnotetext{
5 Other contributions to this conference having a direct connection with gold dinar focused on it as an alternative to fiat money, its place in fiqh, comparison with gold standard, efficacy of the legal system to accommodate it, political and regulatory issues involved, and the erection of an economy based on it.

${ }^{6}$ For example, see the section entitled: Observed Modus operandi of the international monetary players (pp. 36-40. Here even if we take his demonstration as valid, Meera is confusing the manipulation of the system with its merits.. To clinch his point he must show further that such manipulations did not take place, cannot take place, and would not take place under the gold-based monetary system. The world monetary history prior to 1971 is not entirely free of such policies initiated by the IMF.

${ }^{7}$ But adopting a different unit of account is no big deal; it involves merely multiplication by a scalar if unit of account has a fixed relationship with a unit of exchange. For example, Islamic Development bank uses Islamic Dinar as a unit of account but keeps it tied to SDR of the IMF on a one to one correspondence.
} 
disintegration in 1920s. The revival of gold dinar is, he seems to believe, an Islamic imperative. The author found ample support for his ideas at various conferences and in writings on the subject; even as that support now tends to decline.

The writings on gold dinar referred to above have led the deliberations on the subject in two broad directions. First is a fiqhi inquiry. Is the using of gold dinar (or gold) as money a Shari'ah obligation for Muslims? Second, is the fiat money system inherently more unstable compared to the gold-based exchange rates? Let us have a hurried look at these strains of argument in the literature. Haneef and Barakat (2006) present a survey of the fighi positions on the use of gold (and silver) as money available in both the Arabic and English writings ${ }^{8}$. They find the fiqhi opinion - past and present - divided on the issue if gold and silver could alone be Islamic money or it can assume other forms as well? Some of the scholars argue that only gold and silver can be used as money. Others maintain that there is no such compulsion: materials other than gold and silver could also be used as money (p.32) ${ }^{9}$. They cite the principles of ibadah and maslaha to invoke the allowance of discretion in the matter.

Interestingly, even as the two fiqhi viewpoints are found much divergent, both are equally acceptable to Haneef and Barakat. They avoid taking positions (p. 32). But fencesitting with the gaze alternating between the opposite positions does not help resolve problems ${ }^{10}$. The paper has other weaknesses also: there are not a few loose strings hanging untied in their argument. For instance, the authors do mention that some fuqha allow the use of things other than gold and silver as money, but they (authors) are not categorical if the total abandonment of the use of these metals is permissible? We shall have occasion to take up this question later. Presently, we turn to another point in their paper: the fact of countries using gold and silver simultaneously as money: a fact other

\footnotetext{
${ }^{8}$ The coverage of the literature in the survey is quite comprehensive and one need not go over the treaded area once more.

${ }^{9}$ The authors also raise some related issues: will gold and silver create greater stability? Is using gold and silver practical? Is gold backed system the answer? Or, what is the role of the government? (pp. 30-31). But in these matters they do not indulge in any serious discussion; they are largely whistling in the dark.

${ }^{10}$ Of course, discussion is needed and agreeing not to agree may be a part of scholarship (p.32) but remaining stuck in a state of indecision on vital issues is no scholarship, much less practical sagacity. The authors must have elaborated for readers benefit as to how a division of opinion can lead to a workable policy design? Of course, alternatives may stay on board.
} 
Islamic economists also mention but do not show understanding as to when the system could or could not work ${ }^{11}$.

In monetary history, the system is referred to as bimetallism. Silver was brought in to serve as money to meet the growing shortage of gold relative to the monetary demand of the expanding economies. Under the system the coins of both gold and silver used to circulate side by side as standard money - a term we shall soon explain. The exchange rate between the two coins was fixed in the ratio of their prices announced by the mint. However, the price ratio of the two metals in the market often remained different. The metal which became relatively cheaper in the market compared to the mint ratio worked - following Gresham's law -- as bad money and drove the good money i.e. the coins of other metal, out of circulation. Thus, in practice it were the coins of just one metal - gold or silver - that remained in circulation. It was then a cumbersome system and the countries stopped using silver as standard money gold alone worked as monetary metal, especially with the drastic fall in the price of silver after the discovery of new mines in Mexico. Silver coins still circulated in many countries but not as standard money. Haneef and Barakat do not even mention bimetallism, let alone inform us if it was in vogue during the period when coins of both the metals circulated side by side in Muslim lands.

This brings us to a third point: the role of seigniorage in a monetary system. The authors mention the issue and it is much talked about in Meera's writings. He has in a recent paper written with Larbani (2006) argued that fiat money system, because of seigniorage plus interest, is not compatible with the objectives of the Islamic Shari'ah while commodity money like gold and silver alone is ${ }^{12}$. It may be rewarding to begin with a look at the historical origin of the term to understand its import in the current circumstances.

In origin, seigniorage meant something claimed by the sovereign or a feudal lord as his prerogative in relation to society. In the context of money, it was the percentage share

\footnotetext{
${ }^{11}$ The authors rightly advise to be aware of monetary history in the context of introducing gold dinar, especially as one has not to travel far. Interestingly, the authors hardly make use of such awareness

${ }^{12}$ Although interest and fiat money exist together, even reinforce one another, history bears testimony that one can exist without the other. When notes were representative paper money under the $100 \%$ gold backing interest existed in pre-Islamic era; today Muslim countries are having fiat money with interest free banking.
} 
of the crown in the bullion people brought to the royal mint to get converted into coins. Now-a-days the term is applied to all money, including the credit banks create. Such extension of the term is not appropriate. People do not pay for printing of notes the central bank issues. The objective is not to enrich the crown.

Two types of coins used to be in circulation: (i) standard and (ii) token. The face value of a standard coin equaled its intrinsic value, it was unlimited legal tender in discharge of monetary obligations, and it enjoyed free coinage at the mint. In contrast, the face value of a token coin was more than its intrinsic value, it was limited legal tender, and its coinage was not free ${ }^{13}$. Token coins of various denominations are divisions of the standard coin and the exchange ratio of each to the standard coin is officially fixed ${ }^{14}$. One is not sure if Haneef and Barakat refer to bimetallism when they mention gold and silver coins circulating side by side as money. Or, gold alone was the standard metal while silver coins were just token money; copper coins they mention were certainly so.

In my opinion, there is no longer, if there ever was, a division of money into Islamic and non-Islamic. The fiqhi discussion on the topic is contextual; the existence of gold dinar at a point in time in Muslim societies was no more than an acceptance of the prevalent social convention; it is futile to read into it any Islamic import for today or for tomorrow. Let us make a little digression to see what money is and what it is not.

Human need and ingenuity evolved money to overcome the well-known difficulties of barter i.e. exchanging commodities with commodities. The basic function of money was and remains to tear the two sides of such exchange apart into purchase and sale: we convert our product (goods or services) into money through sale in the market. And the

\footnotetext{
${ }^{13}$ Face value of a coin is what is printed on it while intrinsic value was what it could fetch if sold as metal in the market. Unlimited legal tender means that the debtor could offer standard coins for paying any amount of debt; the creditor could not refuse to accept in favor of any other mode of payment. Free coinage implied that anyone one could take the standard metal to the mint and get it converted into coins. In the early stages the mint took no fee for such conversion but later a small charge was levied to cover costs of minting. It was this charge that initially came to be called seneirniorage in monetary parlance. Token coins have none of the characteristics of the standard coin. Their face value was much more their intrinsic worth, they had no free coinage, and they were limited legal tender e.g. even today the creditor in India can refuse accepting payment in small change beyond a sum of ten rupees.

${ }^{14}$ If the silver coins in Haneef and Barakat circulated side by side as standard coins, bimetallism was then prevalent in the land. If they circulated just as token coins, gold standard was the order of the day. As far as I can recall, it was a case of bimetallism; dinar and dirham were both standard coins; the copper coins they refer to were of course token money.
} 
money so obtained we spent as and when we please to purchase what we want. The ultimate exchange is of (real) goods with (real) goods: money is just a go-between. In an evolutionary process, people at different times and locations found some material which everyone would like to have in exchange of what he produced. General acceptability became overtime the necessary condition for anything to serve as money. Money is accepted because money is accepted is a meaningful circularity, strange though it may look. From hides and skins, through gold and silver, to the modern promise to pay serving as money is a wonderful development, worth more than all the money of Nobel Foundation if it were the product of conscious research.

In the long history of civilizational evolution, man stayed with gold as money for more than 2500 years for some unmatched qualities of the yellow metal over other materials. Over time, as gold shortages relative to monetary requirements threatened its position, a basic question was often raised. Is it necessary for money to be made of something valuable as a commodity? This again is a long tale, fascinating too. It is easy to see that if we could build roads in the air, we could use the land released for cultivation. Alas! Roads could not be built in the air to save land for other uses, but one may be tempted to ask: if worthless chits of paper - promise to pay - could serve as money, why should we waste scarce precious metals for the purpose ${ }^{15}$ ? Is not the insistence on using something valuable as money like insisting that cinema tickets must be printed on chocolates; for, if one does not see the movie one may eat his? ${ }^{16}$

Let us now turn back to look at second question we had raised: is the fiat money system inherently destabilizing, especially inflationary? Mansor (2006) marshals evidence in support of the dinarists ${ }^{17}$ to show that expansion in money supply exerts an

\footnotetext{
${ }^{15}$ Did people discover gold mines, took it out from the bowls of the earth and refined it just to lock it back in the vaults of Central banks to satisfy a psychological urge that money should be of something valuable or should at least be backed by it?

16 The historical association of money with something valuable is, however, strong. An interesting example is that the German mark had virtually lost its purchasing power over night in the 1923 hyper inflation. To arrest the rot new series of marks was issued to replace the old ones at a fixed rate. It was announced that the new issue is backed by the entire German land. This psychological trick worked and prices stabilized, even though a German knew that he could not convert the new mark even for an inch of German land at the treasury. But 2007 is not 1923. In this age such tricks may not work. The most important thing about money is the management of its supply relative to its demand so that its purchasing power remains reasonably stable. The least important thing is its association with something valuable in itself.

${ }^{17} \mathrm{He}$ calls the proponents of dinar as the Dinarists presumably for convenience of expression.
} 
upward pressure on price levels and operates, with interest, as a destabilizing influence on stock prices. The model has some difficulties with data but more important is the question: does his exercise reveal anything new? It is a well established fact in monetary history that general price levels have since long had an upward secular trend irrespective of the monetary standards the world was on. Paul Einzig, for example, had long back shows in the very opening chapter of his book Inflation that prices in the world have been rising over the past five thousand years: the upward legs of the cycles tended to grow longer, and downward turns sharper, while the bottoms were agonizingly broader, recovery being slow and painful. Money incomes -- not necessarily money supply ${ }^{18}$ tended to expand faster during inflation than real economy. Proving that fiat money system is inflationary does not cut much ice; one must, in addition, bring evidence from the history of gold standard to show that things were better under that system. Unless one can juxtapose comparative pictures, one is not on firmer grounds.

\section{Stability and gold standard ${ }^{19}$}

Return to gold standard is advocated for having exchange rate stability. In practice, not in theory, exchange rates do diverge much among countries, if left unattended to fluctuate. The divergences add to the risks of international trade, its volume suffers. Inter-country loans play a significant role in smooth running of international finance. Loan contracts are usually made in the currency of the creditor country for obvious reasons. The debtor remains in the dark as to how much shall be the burden of the principal plus interest in its own currency in the coming years. The risk of international borrowing tends to magnify.

Thus, the fluctuating exchange rates seriously hamper international trade and finance. More so in abnormal times as countries tend to engage in competitive currency depreciation to gain or retain the export advantage. If stability does not impose greater

\footnotetext{
${ }^{18}$ For example, money incomes were found galloping much faster due to tremendous rise in the velocity of circulation V of German mark during the famous inflation of 1923, the increase in money supply Q was relatively insignificant..

${ }^{19}$ The discussion in this section draws on Crowther (1948), Halm (1956) and Kurihara (1967). These books are relied upon because being closer to the event they provide detailed and deeper insights into the working and failures of the gold standard. The publication years of these books are not of their first editions or prints. All three contain useful material on gold standard, its working, utility, and limitations in its changing forms up to the IMF mixture.
} 
costs than gains, it indeed is worth pursing. However, gold standard was not adopted after any conscious weighing of the advantages and disadvantages of exchange rate stability ${ }^{20}$. It came out naturally from the historical evolution of money. Currencies were initially made of metal; in course of time gold becoming the dominant choice.

Clearly, if actual gold coins constituted any two currencies, the value of one must remain stable in terms of the other: there could be no room for fluctuation in value of 20 grains of gold relative to fifty grains. Paper money grew gradually out of gold coinage. The era of $100 \%$ reserve for note issue - the cherished dream of some Islamic finance theorists - was indeed very short. As a first step, a certain portion of (legal) money was allowed to consist of currency notes convertible into gold which could circulate along with coins. One-on-one reserve of gold for paper currency was not needed to ensure convertibility as all people were rarely expected to seek conversion of their notes at the same time. Schemes of keeping reserves varied among countries ${ }^{21}$. But the common element of them all was to have and maintain an overall relation between the gold held in reserves and the volume of currency in the country. Gold controlled the volume of money in circulation through keeping a minimum gold reserve, however defined. To invoke public confidence, monetary authorities had to keep the price of gold stable in the country. This was the essence of what is called the domestic gold standard.

Could gold standard as described above ensure price stability at home? In theory, gold standard does not stabilize price levels as it does not stabilize the volume of currency in a country. It merely stabilizes the relation between the volume of gold and the volume of currency But if the volume of gold itself fluctuates, the domestic gold standard does not stabilize the volume of currency, rather it forces it to fluctuate (Crowther 1948, p.286). Thus, gold standard offers no guarantee for internal price level stability ${ }^{22}$. The history of gold standard confirms this conclusion: it is replete with examples where the

\footnotetext{
${ }^{20}$ It was presumably during the 1930s that stung by exchange rates instability during and after the Great Depression the considered opinion saw more advantages than disadvantages in Gold Standard leading to its restoration in a diluted form in the IMF scheme. The dinarists are borrowing arguments from the debate that has little to offer as much water has since turned in the Red Sea.

${ }^{21}$ For a brief discussion of these schemes, see Crowther (1948, pp. 281-300)

${ }^{22}$ A reduction in the volume of currency may cause a reduction in the quantity of money or it may not the two can, on occasions, run divergent courses. See Crowther (1948, p. 297 where he also mentions a few historical examples of such diversions with reasons).
} 
influence of gold standard on prices was found wanting: it failed to curb inflation or to prevent depression. Instead, it broke down.

The limitations of domestic gold standard are aggravated if extended to international arena. Its international component is concerned with the external value of a currency. The denarists believe that linkage with gold can ensure its stability, while Mansor (2006) seems to support them by implication. Logic and history both negate their conclusions.

It may be useful to begin with the reiteration that the domestic gold standard was part of the evolution of money, not the result of 'invention'. For, its extension to external transactions too was part of the same natural process. When gold coins constituted most of the money supply in two countries, there was little room for variations in the exchange rate between them. So long as bank deposits in the two countries A and B were freely convertible into gold at fixed prices, the exchange rate between them could not vary from their mint parity by more than the small margin of what were called the gold points. Any demand for foreign currencies that could not be met in the foreign exchange market at a rate within say 0.5 percent on either side of the mint par was shunted out to the gold market. Thus, the demand for any currency in the foreign exchange market always equaled its supply. The gap was covered by the gold movement between the two countries. Figure 2 explains the automatic nature of the balancing mechanism.

To understand the working of the international gold standard the Figure depicts, let us assume that currency A contains 3.2727273 grains of gold 11/12 fine while currency B has 10 grains of gold 9/10 fine. The mint par (the domestic price of foreign

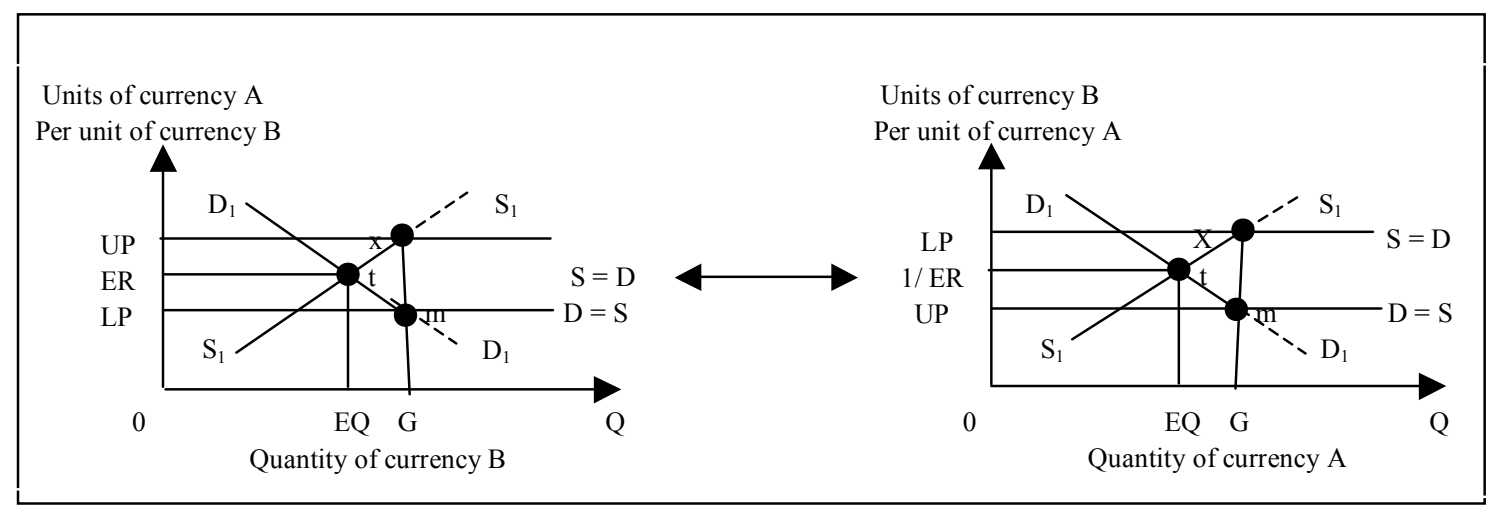

Figure 2: The Gold. Standard Mechanism 
currency ER) of the two currencies will then be:

$$
\text { For A } \frac{10 \times \frac{9}{10}}{3.2727273 \frac{11}{12}}=3 \text { per unit of } B
$$

For B Reciprocal of 3 i.e $=0.333333$ per unit of $\mathrm{A}$

Assume further that the cost of exporting gold worth 3 units of currency A between the two countries is 0.0005 units of currency A. Thus, in the foreign exchange market of country A the exchange rate $3+0.0005=3.0005$ will be the upper gold point (UP), and the lower gold point (LP) will be $(3-0.0005)=2.9995$. We now have the apparatus to explain how gold standard would operate between the two countries.

If the demand for B currency starts rising relative to its supply in country A - the balance of payments moves against it - the exchange rate in the market will start rising ${ }^{23}$ but it cannot cross the $\mathrm{UP}^{24}$ as it will become cheaper for importers to buy gold in the market and export it to country $\mathrm{B} . \mathrm{D}_{1}$ will cease shifting up: any more; excess of demand will move out from the currency market to that of gold, allowing only a tiny (tx) departure from ER.. In contrast, if the balance of payments becomes increasingly favorable to country A, raising the supply of B currency relative to its demand in the exchange market, the ER will start falling: currency A will become dearer in country B. But the process cannot go on unabated. As soon as the rate crosses the upper gold point which would be the same as LP in A -- again a small divergence (tm) from ER - the importers in country B will find it cheaper to ship gold to country A rather than buy urrency in the exchange market. Under gold standard no country can stop either export of gold or its import. Gold standard works on the assumption that at gold points the supply of the metal is kept perfectly elastic.

The implications of this assumption are indeed far reaching. The mechanism keeps the exchange rates between currencies fixed in relation to one another as they are tied to a common beam: the price of gold. But it does not necessarily keep the rates stable; it only makes them fluctuate in response to the changing demand and supply conditions of gold

\footnotetext{
${ }^{23}$ For a real world illustration see Halm (1956, pp.176-177-). He explains how the exchange rate between USD and Pound Sterling was settled when both countries were on gold standard during the inter-war period ${ }^{24}$ It may be noted, as shown in Figure 2, that the gold export point of one country becomes the gold import point of the other country and vice versa
} 
affecting its price. Gold standard forces a country to import inflation or deflation taking place outside via the gold link; it makes lurch and swing an otherwise stable economy to

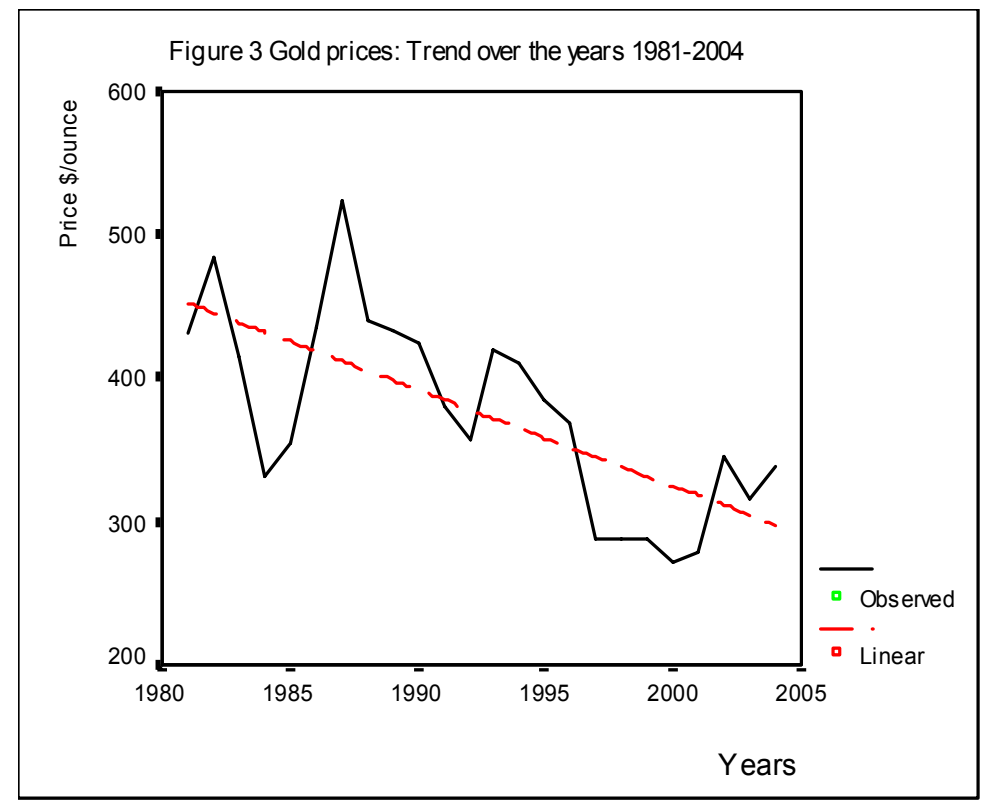

Source of data: Web: US Gold

external tunes. Notice further that the stability in gold prices is a thing of the past. Recently, for quarter of a century gold prices have struck a pronounced deflationary trend as shown in Figure 3.

The denarists must investigate the impact of the phenomenon on their schemes. I resist the temptation of indulging in such an exercise because these schemes, I must admit, are not very clear to me. The difficulty with most of the econometric excursions is that their results are specific to the period the data cover. They are found very weak on the prediction front. One may really find it revealing to apply a Mansor type model to the period Figure 3 covers with editing of data for consistency

Stability of exchange rates is desirable, rather necessary, in this era of globalization for promoting free trade and liberalization, but on a return to gold only the naïve will insist. Let me explain very briefly the reasons as to why the return is neither desirable nor practicable. One of these i.e. the issue of internal stability, I have already touched upon. Under the strict rules of the game, it is realistic to assume that the central bank of country A keeps gold in reserve just what is obligatory, say $40 \%$ of notes in circulation, to ensure their convertibility. Suppose now that there is an inflow of gold, 
ignoring reasons, worth $\$ 1$ million. This moves into the reserves of the central bank. If it does not, as it cannot, build a buffer stock of gold, it must put additional notes worth $\$$ 2.5 million in circulation. And if the banking system is to maintain a $10 \%$ reserve for credit creation the economy would become awash with a monetary expansion of $\$ 25$ million. This multiple expansion of money supply may impose inflationary pressures on an otherwise stable economy. You may work out the deflationary potential of gold out flow of a similar magnitude. In fact, gold standard inherently carries a deflationary bias: a country losing gold must contract credit but the one receiving it is under no compulsion to expand credit.

Gold standard can work smoothly if prices - wages in particular - were reasonably flexible, there were no structural rigidities in the economy, and public authorities were willing to surrender their discretion and independence to the automation requirements of gold standard mechanism. The suspension of gold standard under adverse circumstances in the past was the proof of the unwillingness of policy makers to accept such surrender. ${ }^{25}$ This unwillingness has only become more obstinate with the passage of time. This obstinacy was one of the reasons why the original designers of the IMF scheme rejected a return to gold standard so as to impart a measure of flexibility in the arrangement; the amendments of 1978 buried the gold-link for good.

Until the beginning of the last century the measure of money requirements was the amount of the work money had to do, largely as a medium of exchange. Given the velocity $\mathrm{V}$ of money circulation, the measure was in close harmony with the level of real output. Even as per this criterion, the quantity of money needed could initially be managed; but gold supplies soon fell short to meet the monetary needs of economic expansion and currency notes with partial metal backing soon appeared on the scene to supplement coins. Compare this situation with the current scenario.

During the second half of the last century the real output the world produced was more than what it could during its entire existence before 1950. Where is the gold to support money expansion to match the increase? The growing volume of financial transactions knows no bounds. More than a trillion US\$ go round the world stock

\footnotetext{
${ }^{25}$ For a detailed explanation of the monetary expansion and contraction processes under the gold standard and their repercussions, see Halm (1956, Chapter 12, section 4 pp. 189-192).
} 
markets every twenty four hours in speculative trading. It is estimated that the volume of money involved in foreign exchange spot transaction alone is 70 times of the money value of world's real output. Supply of money tied to gold would fail to meet the money requirements of the modern age. One may be fond of day dreaming but return to gold is not even worth that dream. Today, financial transactions are an ocean wherein real transactions are just a tiny island. Return to gold is not possible.

\section{Gold and bilateral trade agreements}

The dinarists strike a shifty stance and want to go for testing waters and gaining experience by first using gold (dinar) in bilateral trade balance settlements between Muslim countries. We shall argue that this too is not a tenable proposition. Let us define a few symbols to fix ideas.

$\begin{array}{cl}\mathrm{G} & \text { Physical quantity of gold in ounce units } \\ \mathrm{PG}_{\$} & \text { International price of gold in US dollars } \\ \mathrm{PG}_{\mathrm{A}} & \text { Price of gold in the currency of country A } \\ \mathrm{PG}_{\mathrm{B}} & \text { Price of gold in the currency of country B } \\ \mathrm{R} & \text { Exchange rate of currency A per unit in terms of currency B i.e. } \mathrm{PG}_{\mathrm{B}} / \mathrm{PG}_{\mathrm{A}} \\ \mathrm{Q}_{\mathrm{XA}} & \text { Quantity of goods exported from country A to country B } \\ \mathrm{P}_{\mathrm{XA}} & \text { Prices of exports from country A to country B in A's own currency } \\ \mathrm{Q}_{\mathrm{MA}} & \text { Quantity of goods country A imports from country B } \\ \mathrm{P}_{\mathrm{MB}} & \text { Prices of goods A imports from country B in latter's currency. }\end{array}$

Now, we may have the balance of trade of country A in terms of physical ounces of gold G as under:

$$
\begin{aligned}
G & =\frac{\mathrm{Q}_{\mathrm{XA}} \cdot \mathrm{P}_{\mathrm{XA}}}{\mathrm{PG}_{\mathrm{A}}}-\frac{\mathrm{Q}_{\mathrm{MB}} \cdot \mathrm{P}_{\mathrm{MB}}}{\mathrm{PG}_{\mathrm{B}}} \\
& =\left[\frac{\mathrm{Q}_{\mathrm{XA}} \cdot \mathrm{P}_{\mathrm{XA}}}{\mathrm{PG}_{\mathrm{A}}}-\frac{\mathrm{Q}_{\mathrm{MB}} \cdot \mathrm{P}_{\mathrm{MB}}}{\mathrm{R} \cdot \mathrm{PG}_{\mathrm{A}}}\right] \text { where } \mathrm{R}=\frac{\mathrm{PG}_{\mathrm{B}}}{\mathrm{PG}_{\mathrm{A}}} \\
& =\frac{1}{\mathrm{PG}_{\mathrm{A}}}\left[\mathrm{Q}_{\mathrm{XA}} \cdot \mathrm{P}_{\mathrm{XA}}-\frac{\mathrm{Q}_{\mathrm{MB}} \cdot \mathrm{P}_{\mathrm{MB}}}{\mathrm{R}}\right]
\end{aligned}
$$

If in country $A$ price of gold $P_{A}=\left(P_{\$} / a\right)$ where $P_{\$}$ is the international price of gold expressed in US dollars and ' $a$ ' $>0$. Thus, if we divide the dollar price of gold by ' $a$ ', we obtain the international price of gold in units of currency A. Likewise, if $\mathrm{PG}_{\mathrm{B}}$ were equal to $\left(\mathrm{PG}_{\$} / \mathrm{b}\right)$, we will get the international price of gold expressed in 
currency B. These definitions give us:

$$
\frac{\mathrm{PG}_{\mathrm{B}}}{\mathrm{PG}_{\mathrm{A}}}=\frac{\frac{\mathrm{PG}_{\$}}{\frac{\mathrm{b}}{\mathrm{PG}}}}{\frac{\mathrm{P}}{\mathrm{a}}}=\frac{\mathrm{PG}_{\$} \cdot \mathrm{a}}{\mathrm{b} \cdot \mathrm{F}_{\$}}=\frac{\mathrm{a}}{\mathrm{b}}=\mathrm{R}
$$

Some implications of the above stated relationships may be noted. $G$ is the balance of trade of country A in the physical quantity of gold. If we multiply $\mathrm{G}$ by the domestic price of gold - here $\mathrm{PG}_{\mathrm{A}}$ - we get the balance of trade expression in domestic currency. If we multiply $\mathrm{G}$ with dollar price of gold $\mathrm{PG}_{\$}$, we obtain the trade balance of $\mathrm{A}$ in US dollars. The ratio $\mathrm{a} / \mathrm{b}$ i.e. $\mathrm{R}$ is the exchange rate per unit of currency $\mathrm{A}$ in terms of currency $\mathrm{B}$ with

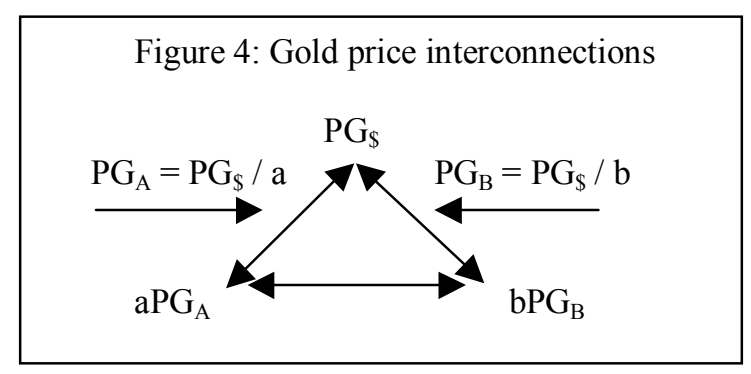

reference to the dollar price of gold. The observations can also be seen from the side of currency B. The three gold price ratios must be consistent with one another in a system of exchange rates the proponents of gold dinar envisage.

\section{Example 1:}

$\begin{array}{lclc} & \text { USA } & \text { Malaysia } & \text { Pakistan } \\ \text { Gold price per ounce } & \$ 600 & \text { RM 2200 } & \text { PKR 36600 } \\ \text { Exchange Rates } & \mathrm{RM} / \$=3.67 & \mathrm{PKR} / \mathrm{RM}=16.64 & \mathrm{PKR} / \$=61 \\ \text { Good Exported } & & \mathrm{Q}_{\mathrm{XM}}=100 \rightarrow \mathrm{Q}_{\mathrm{MP}}=50 \\ \text { Domestic Price per unit of Q } & \mathrm{RM} 1000 & \mathrm{PKR} 15000 \\ \text { Value of Q in Domestic Currency } & \mathrm{RM} \mathrm{100,000} & \text { PKR 750,000 } \\ \text { Put values in (3.1) and solve to get } & \mathrm{G}=25 \text { Ounce } & \mathrm{R}=16.64\end{array}$

$$
\text { And from (3.2) get } \mathrm{a} / \mathrm{b}=0.273 / 0.0164=16.64=\mathrm{R}=\mathrm{PKR} / \mathrm{RM}
$$

Let us assume that the above details remains the same except that prices of gold in the two countries Malaysia and Pakistan change to RM 3400 and PKR 36000 respectively. The two equations would now yield the following results:

$$
\mathrm{G}=20.83 \text { Ounce, and } \mathrm{a} / \mathrm{b}=15=\mathrm{R}=\mathrm{PKR} / \mathrm{RM}
$$

It is easy to see that: 
1. Gold linkage is not enough for ensuring stability of exchange rate; it must fluctuate with changes in the price of gold in the two countries. The equation between currencies can be maintained only when sale and purchase of the metal at a fixed price is part of the scheme. Without this measure even the denomination of trade in gold / gold dinar instead of paper currency hardly serves any useful purpose. It will only add to the complexities of bilateral trade agreements.

2. Converting exports and import first into gold and the balance into US dollars is a cumbersome process. It is frivolous and will add to trade risks. One risk is due to fluctuation in the relative price of gold in the two countries ${ }^{26}$. Another is related to the conversion of gold balance back into US dollars as, unlike the assumption in the example, that currency (USD) is not linked to gold. The time interval involved in each conversion and between them is of crucial importance. A better course of action would probably be to convert the import and export values expressed in local currencies into US dollar directly ${ }^{27}$.

3. However, if any of the countries - Malaysia or Pakistan - decides to buy and sell gold at a fixed price, it may set into motion international arbitrage operations, even if clandestine, and may play havoc with the smooth running of the economy. As Muslim countries share among themselves a meager portion of their aggregate foreign trade - not more than $15 \%$ presumably - and have an overall deficit with the rest of the world, the scheme brings us face to face with the peril of draining gold out from the Muslims to the rest of the world. The fact that Muslim countries produce annually less than $10 \%$ of total output of the yellow metal cannot be over looked in this context. Indonesia alone is a country of some importance in the matter as Figure 5 below indicates. The denarists seldom take note of these facts. It is instructive to note that in a not too old empirical study Retner (1992) finds that gold prices have shown much erratic behavior since 1972 which is difficult to

\footnotetext{
${ }^{26}$ To avoid this risk, it is suggested that exporters would be paid in their respective national currencies by their central bank on the date of export, based on the gold dinar exchange rate prevailing at the time of transaction. See Thani and Thani (2003, p.27). This raises a few queries. Will the exporter be deprived of all his export earnings in foreign exchange? What if he does not want to bring money home? How will imports be financed? What formula will determine the terms of trade for a country? Clarification is needed.

${ }^{27}$ The point was made by M.U. Chapra during the discussion in IDB Seminar (2003).
} 
explain (p.93) ${ }^{28}$. The author uses relevant data for the period June 1973 to December 1988. He concludes on the basis of his test results that gold functioned as a weak hedge against inflation until 1979, and in the following periods it could provide no protection against rising prices. Gold prices were also regressed on the dollar foreign exchange rates of six major industrial countries - Canada, France, Italy, Japan, West Germany, , or the United Kingdom It was found that here also

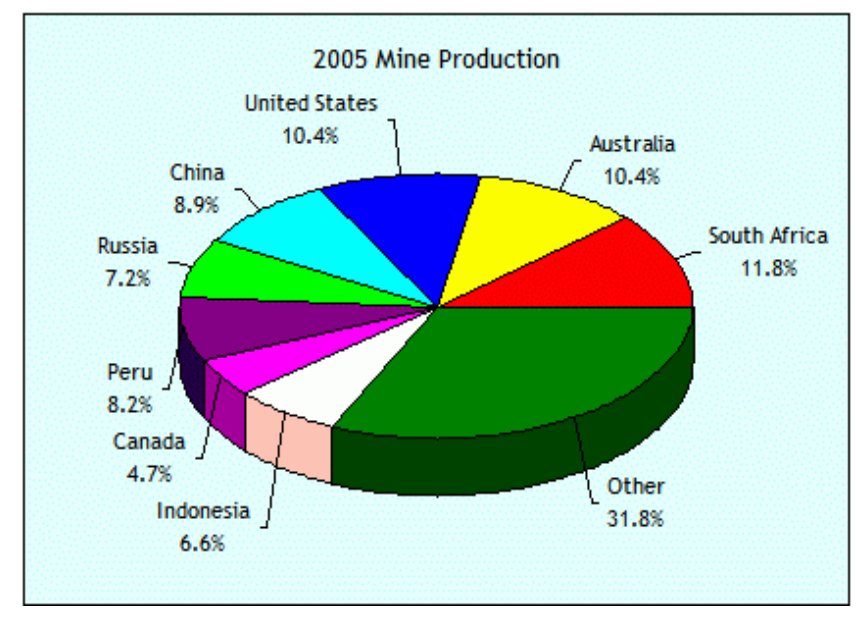

Source: Internet -World Gold Production (Gold sheet)

Figure 5: Production of gold in 2005

gold provided no hedge against the decline of US dollar vis-à-vis these currencies (p.97). The denarists may want to undertake a similar exercise for Malaysia.

\section{Concluding Remarks}

Much of the present paper talked of gold standard from a historical perspective. In that it can claim little that is original. However, what is not original was not unessential. It was needed to remove many cobwebs in the thinking on gold dinar as a panacea to all economic difficulties Muslims are currently facing. One problem with the denarists is that they do not stick to what they say even for a moment. Do they want a return back to gold as money in Muslim countries? Is it their position that having gold dinar as currency is a Shari'ah imperative for Muslims? Is it gold or gold dinar that they argue for standard at the international level? ${ }^{29}$ Are they saying that gold dinar should be used in bilateral

\footnotetext{
${ }^{28}$ Refer to Figure 1, section B as a support where the coverage is of a much longer period.

${ }^{29}$ The subtitle 'Returning to gold' in upper case letters of Meera's book - 'Theft of Nations' -- as also passages in the text suggest that the author wished the revival of the 'golden age' to save developing countries from the stealing of their wealth by the rich West. A more appropriate term would probably be the thuggee - a Hindi word that Oxford dictionary recognizes since long. In fact, the author talks about
} 
trade agreements? They tend to answer such questions in the affirmative and the negative almost in the same breath. I have attempted to focus on some basic positions the dinarists seem to take. In brief, the conclusions that follow from the foregoing discussion are as under:

1. Return to gold standard at the international level is not considered either desirable or practicable for some strong reasons. These were clearly spelled out by J. M .Keynes in his position paper of 1938 quoted in Halm (1956) The managed currency system of the IMF enforced in 1946 did maintain the gold linkage of national currencies, but diluted the rules of the old game considerably. The 1978 amendments to the IMF articles specifically forbade members to express the value of their currencies in terms of gold. This realization presumably is the reason why denarists no longer talk of returning to gold standard.

2. Unless gold standard is international, there is no point in having domestic gold standard. It is found working neither as a hedge against inflation nor as a better investment alternative. In a world conceived of as a global village, gold-link may create more problems than it may resolve; even if restricted to bilateral trade only.

3. Having gold dinar as money is not a Shari'ah requirement ${ }^{30}$. The Fiqh Academy is not opposed to the use of fiat money in Muslim countries. The denarists may like to seek confirmation on the point. ${ }^{31}$. The use of seigniorage notion to attack the fiat money is untenable; it is too stretchy, rather inapplicable.

4. The issue in monetary economics is to keep the supply of money under control, not of its being made of something valuable as a commodity. Using gold for the purpose is akin to a blind man leaning against the lamp post for rest not for illumination. Alert and efficient management of money supply with adequate

what stemmed from a misunderstanding during the 1997-1998 financial crisis in Malaysia. The Kuala Lumpur composite (stock price) index KLCI fell from over 1000 to around 600 over the year! This created the impression that Malaysia was robbed of its wealth by the foreigners, especially Soros, the American fund manager. This was surprising. For, the money that went out of the country legally belonged to those who transferred it abroad. More than that, all real wealth - ports, roads, factories, buildings, and scenic beauty and so on - remained intact. Nothing real was lost. Meera could hardly mention anything substantive in his charge sheet.

${ }^{30}$ In prophet's time gold was adopted as standard because it was then prevalent.

${ }^{31}$ Fiat money exists in a country even under gold standard unless we keep equivalent gold in reserve for each note in circulation. If the dinaries are arguing for a $100 \%$ reserve system is not very clear. 
credit and capital controls in place can and is delivering results e.g. in China and India. Manage the economy properly, keep a watch on domestic prices, and build strong diversified foreign exchange reserves. You can ensure stability of both the price level and the exchange rate. Let it be known that fiat money is not an exclusive terrain for corruption to thrive, the history of gold standard bears ample evidence that the abuse of the system was not entirely absent then too.

In the light of the above discussion, I believe it is time that we banish gold (dinar) as money from all serious discussions in economics - mainstream or Islamic.

\section{References}

Crowther, G. (1948 Second Edition):An Outline of Money, Thomas Nelson and Sons Limited, London, UK (Chapter IX, PP. 277-335)

Einzig, Paul (1950): Inflation, Macmillan,London

Gupta, S. B (1990: Monetary Economics: Institutions, Theory and Policy. S. Chand \& Co. Delhi

Halm, George N. (1956 Print): Monetary Theory: A Modern Treatment of the Essential of Money and Banking, Asia Publishing House, Bombay, India (Chapter 12, pp. 171-209).

Haneef, M. Aslam and Barakat, E. Rafiq (2006): Must Money be Limited to Only Gold and Silver: A Survey of Fiqhi opinions and Some Implications, JKAU: Islamic Economics, Vol. 20, No. 1, Jeddah (pp. 21-34)

Hasan, Zubair (2003): Efficacy of Gold Dinar - A Note, presented at the Senior Experts Workshop on Gold Dinar, IDB Headquarters, Jeddah.

Ibrahim, Mansor H (2006): Monetary Dynamics and Gold Dinar: An Empirical Perspective, JKAU: Islamic Economics, Vol. 20, No. 1, Jeddah (pp. 3-20)

Kurihara, Kenneth, K. (1967 print): Monetary Theory and Public Policy, Unwin University Book, London W. C. I (Part III Domestic versus International Equilibrium)..

Meera Ahmed Kameel Mydin, and Aziz, H. A. (2002): The Islamic Gold Dinar: Socio-economic Perspectives: see the proceedings of 2002 International Conference on Stable and Just Global Monetary System: Viability of Islamic Dinar, International Islamic University, Malaysia PP.151-176).

Meera Ahmed Kameel Mydin and Mousa Larbani (2003): The Gold Dinar in Multilateral Trade: A Mathematical Model for determining an Efficient Trade Matrix, International Banking Conference, Prato, Italy

Meera, Ahmed Kameel Mydin (2004): The Theft of Nations: Returning to Gold, Pelanduk, Kuala Lumpur 
Meera Ahmed Kameel Mydin and Mousa Larbani (2006): Seigniorage of Fiat money and the Maqasid Al Shari'ah: The compatibility of gold dinar with the Maqasid, Humanomics Vol.22, Issue 2, Emerald Group Publishing Limited. (pp.84-96)

Othman, Jalallulail (2002): The Legal and Regulatory Infrastructure in Malaysia for the Implementation of the Dinar as a trading Currency, in proceedings of International Seminar on Gold Dinar in Multinational Trades, Institute of International Institute of Malaysia

Ratner, Mitchell (1992): Inflation, Currency Devaluation, and the price of Gold, American Business Review (pp.93-97).

Thani, N. Nazrul and Thani, N. Hasan (2003): Using Gold in International Trade Settlements: The Legal and Regulatory Issues in proceedings of 2002 International Conference on Gold in International Trade: Strategic Positioning in Global Monetary System, Kuala Lumpur

Vadillo, Umar Ibrahim (2003): The Architect: An Academic Perspective of the God Dnar Economy in proceedings of 2002 International Conference on Gold in International Trade: Strategic Positioning in Global Monetary System, Kuala Lumpur (pp.335-360). 